\title{
PALB2 Gene
}

National Cancer Institute

\section{Source}

National Cancer Institute. PALB2 Gene. NCI Thesaurus. Code C84945.

This gene may play a role in the repair of DNA damage that is resolved by recombination. 